Escaping the Nation in the Middle East: A Doomed Project? Fanonian Decolonisation and the Muslim Brotherhood

Jasmine K. Gani*

School of International Relations, University of St Andrews, Fife, Scotland, United Kingdom

*Email: jkng@st-andrews.ac.uk 


\section{Escaping the Nation in the Middle East: A Doomed Project? Fanonian Decolonisation and}

\section{the Muslim Brotherhood}

This article has two goals: first, it seeks to outline the dissonance between nationalist self-determination and a decolonial pursuit of independence using Fanon's blueprint for decolonisation. Second, it interrogates the decolonial potential in Fanon's blueprint, and asks whether anti-colonial groups can ever truly escape the inheritance of a Eurocentric nation-state despite their decolonial intent. To explore these themes, the article focuses on Hasan Al-Banna's ideology and vision for the Muslim Brotherhood in the first half of the twentieth century. In its search for independence from the British, his movement rebuffed liberal models of national self-determination and pursued an alternative political imagining that was delinked from the coloniality of the nation-state. Drawing upon Banna's memoirs, speeches and political tracts and Frantz Fanon's The Wretched of the Earth, this paper explores the parallels between Banna's vision of independence and Fanon's decolonial call for international solidarities and national consciousness as alternatives to nationalism. The paper goes on to argue that, ultimately, anti-colonial groups such as the Muslim Brotherhood have struggled to escape the colonial tethering of independence to the nation-state and its various trappings of coloniality.

Keywords: Fanon; Nation; Muslim Brotherhood; Hasan Al-Banna; Decolonisation

\section{Introduction}

Frantz Fanon's The Wretched of the Earth, is commonly recognised as a powerful critique of the capitalist legacy of colonialism in the postcolonial world (Forsythe, 1973; Nursey-Bray 1972; Rabaka, 2011; Salem 2018). The role of the "native bourgeoisie" in upholding colonality even after decolonisation tends to be the focal point of analyses of Fanon's work. However, earlier debates on Fanon (which are less cited in recent works) focused on his stance on nationalism and the nation-state (Miller, 1990; Bhabha, 1991; Lazarus, 1993). Throughout Wretched of the Earth, Fanon decries "nationalists" who exploit their position as so-called leaders of the anti-co- 
lonial movement, to morph into elite interlocutors between the former colonisers and the poorer, uneducated, rank and file. The inherent coloniality within nationalism, bequeathed by the colonisers after the rise of Wilsonian liberalism is often overshadowed by a class-based analysis. And yet the two are inseparable. Quijano (2000) and Mignolo's (2002) matrix of coloniality posits the interconnected relationship between economic production and knowledge production. If capitalism spearheaded economic colonisation, then nationalism aided an intellectual and cultural imperialism rooted in racial supremacism; meanwhile, the nation-state acted as an operational vehicle for both. A purely Marxist analysis challenges the economic legacies of colonialism, but still enables Eurocentric nationalism to be transplanted with an anti-colonial nationalism. Is this sufficient for a decolonial project? Fanon's work has elicited diverging perspectives on the matter, but I argue an ambiguity of language and concept tempers the radical potential of his blueprint for decolonisation.

To investigate and apply this radical potential, I turn to Egypt as a case-study. Salem rightly points out that scholarly application of Fanon's work has tended to miss out Egypt (2018), which given the changes in its colonial status, regime type and ideological affiliations throughout the twentieth century, provides fertile ground for a Fanonian analysis. Such work, alongside older studies such as Timothy Mitchell's classic Colonising Egypt (1988) remind us of the richness of Egypt as a case study for postcolonial and decolonial research. However, while Salem's work focuses on the ruling elites - under British rule through to the presidency of Anwar Sadat - this article turns its attention to the decolonial potential of the marginalised but nevertheless influential Muslim Brotherhood. Social forces beneath and outwith the ruling elite can often be overlooked in contexts where the ruling elite also happen to be anti-colonialists. But as Tara Povey 
points out, the study of social movements even in authoritarian systems is crucial in diversifying our understanding of postcolonial societies (2015); it is also useful in challenging monopolies of anti-colonial narratives and prescriptions, particularly when (in this case) the post-colonial Egyptian state had the administrative and political capacity to operationalise its agenda, and was able to convey its ideology via state media and infrastructure, while post-colonial social movements could not.

Prior to Nasser's rise, non-state movements flourished in their ideas and activities, even under British rule and independent of the Egyptian bourgeoisie. This makes the pre-Nasser era an interesting case: the inter-war period was a time of upheaval and uncertainty, but also offered fresh political and intellectual opportunities - this was particularly so in Egypt which produced a multitude of anti-hegemonic groups in this time (Pankhurst, 2013: 64). What can they tell us about societal resistance and decolonial imaginings beyond the ruling elites? Particularly when they were not as trapped within the architecture of the nation-state as their state counterparts. The Muslim Brotherhood in particular offers an interesting case study, firstly because there are very few accounts of a Fanonian application to the Muslim Brotherhood (and vice versa), and secondly because they initially offered a very clear and robust challenge to the rubric of the capitalist, ethno-supremacist nation-state. Given that is the case, they provide a useful lens through which to explore the possibilities and limitations to Fanon's framework of national consciousness.

In the first section, the article expounds the ways in which the foundations of the European nation-state and the ideology of nationalism were racialised and constituted by supremacism, even after being upgraded and repackaged by Wilsonian liberalism. The following section scrutinises the decolonial potential in Fanon's Wretched of the Earth and considers its ambi- 
guities regarding nationalism. Using Cemil Aydin's (2017) and S. Sayyid's work (2014) on the role of the Caliphate in providing a powerful counter-imaginary to the nation-state, section three explores the ways in which Hasan Al Banna's ideology articulated a decolonial response to Fanon's evident ambivalence towards nationalism. And finally, the article returns to the foundational question: to what extent was Banna successful in using a religio-political consciousness to resist Wilsonian decolonisation as Fanon prescribed? Can third-world movements whose nationalism is informed by anti-colonialism avoid being drawn into a modernist nationalist framework that imposes nationhood as a standard of civilisation, or will their (and any) nationalism always be drawn to and interlocked within the trappings of Eurocentric nationalism? I argue that ultimately, while third-world anti-colonial movements sought to cultivate their own, indigenous brand of nationalism that eschewed the racism and imperialism of western nationalism, in many cases, such as that of the Muslim Brotherhood, they nevertheless failed due to the structuralisation of coloniality and nationalist competition.

\section{The Racist Constitution of the Nation-State and Wilsonian Decolonisation}

Critical scholars have rightly reflected on the Eurocentrism of the nation-state (Seth, 2011; Sajed, 2013; McCarthy, 2009) and the constitutive role of supremacism and racism in the foundations of European and American nationalism (Dunbar-Ortiz, 2018; Vitalis, 2015: 63;

Goldberg, 2002). Firstly, the rise of the nation-state and nationalism coincided with the so-called 'age of exploration', which requires one to confront the ways in which violence, genocide and dispossession of indigenous people contributed to notions of self and identity in colonial states in Europe, the Americas and the Pacific. Secondly, as Thompson argues, "[ $\mathrm{t}]$ he making of European 
nation-states and their expansion...laid the bedrock for entrenched racial orders of the modern world." (Thompson, 2013). Nationalism neatly propped up and was nestled within a global binary framework of 'civilisations' and races (Persaud, 2002). Prior to the fall-out of the First World War, nationalism and aspiration for a nation-state were set up as necessary markers of civilisation that, by default, could only be possessed by the white, civilised western world. Early European and American champions of nationalism constructed nationhood as a primordial destiny conditional on civilisational status. As such, those of perceived inferior civilisational standing were necessarily deemed lacking in national aspiration and incapable of acquiring it. Early modernist writings that questioned the very humanity of non-white people (McCarthy, 2009: 48-58; Bernasconi, 2011), were then overlaid by nationalist theories that obliterated non-white people from nationalist destinies and placed them "outside history" (Sabaratnam, 2011). The assumed inability of non-white people to comprehend the value of nationhood became the upgraded justification for denying them sovereignty.

To give one example of this racist perspective in nationalist discourse, nineteenth century evangelical lobby groups in Britain advocated for the creation of new, western nations in the Middle East to civilise and expunge the 'barbarism' that tainted the Holy Land. Lord Shaftesbury, better known for campaigning for child labour rights, but also a prominent and vocal Christian evangelical lobbyist, argued that indigenous Arabs had no claim to self-determination because they did not possess or constitute a primordial nation (Sharif, 1976; Garfinkle, 2006). It is clear that nationalism and the creation of nations meant different things depending on which side of the global colour line one was standing on. For those people deemed civilised, nationalism equalled independence, sovereignty and equality among citizens (Sayyid, 2014: 26). For those on 
the non-white side of the colour line, it meant giving way to those perceived to have a higher destiny, either to be erased (as in the Americas) or colonised (as in the Middle East).

This exclusion of non-white people, in this case Arabs, from the destiny of nationhood was challenged by a growing Arab nationalist intellectual movement in the nineteenth and early twentieth century, including prominent writers such as Abd Al-Rahman Kawakibi, George Antonius, Rifa'ah At-Tahtawi, and Sati Al-Husri. But rather than critique the framework for its racist and unjust foundations, the early Arab nationalists sought inclusion within it by seeking to prove their likeness to the west (Haim, 1962; Tibi, 1997). However, the greatest boost to Arab inclusion within 'the family of nations' eventually came from a western source. On 8 January 1918, eleven months before the end of the First World War and with the Ottoman Empire already in disarray, US President Woodrow Wilson delivered his address before a Joint Congress, issuing his famous statement: "The other nationalities which are now under Turkish rule should be assured an undoubted security of life and an absolutely unmolested opportunity of autonomous development".

Woodrow Wilson's article 22 and his famous fourteen principles appeared to recognise the presence of nationalities in the Middle East, tantamount to recognition of at least their capacity for civilisation. He also offered the possibility of legally- and politically-recognised nationhood for Arabs in a way that his transatlantic counterparts, such as Lord Shaftesbury, had been unwilling to concede. It marked an important shift in nationalist discourse, not only on the peripheries of academic debate but now brought to the forefront of international diplomacy by the architect of liberal internationalism. By 'upgrading' nationalism, Wilson presented himself (and the concept of the nation-state) as universalist: his advocacy of self-determination appeared to 
give non-white people access to civilisation that had previously been denied to them. The collapse of the Ottoman Empire at the end of the First World War provided the rupture that helped to precipitate the nation-state model via a paternalistic mandate system as the solution for the Arab region.

However, it must be remembered that nationhood was only presented as an aspiration for some non-white people - the privilege was not extended to the rest of non-Arab Africa, while Wilson was pivotal in voting down a proposed article on racial equality during the founding of the League of Nations (Vitalis, 2005: 169). The uneven extension of nationalist privilege created a hierarchy and competition for formerly colonised people to gain membership into the club of civilisation - the so-called 'family of nations'. Moreover, it perpetuated a relationship of subservience as the west installed itself as the model for newly decolonised nations to follow. Thus this apparent watershed in world politics successfully tethered third-world aspirations for independence, to nationalism and the nation-state, ensuring that those seeking to decolonise would never truly escape the coloniality embedded by their colonisers.

\section{Fanonian Decolonisation via National Consciousness and the International Dimension}

The deeply flawed nature of decolonisation as it was presented by liberal internationalists was recognised as such by Fanon in his calls for anti-colonial revolution in The Wretched of the Earth, published in 1961. Fanon problematised decolonisation and delivered a blistering critique of local nationalists for their complicity in maintaining a lingering influence of former colonial powers, chastising them for exploiting the rupture of decolonisation to prop up their own power at the expense of their fellow countrymen and women. Thus for him, the inherent civilisational 
project embedded in Wilson's tantalising offer of self-determination was not a surprise; he maintained a scepticism of banal platitudes that masked continued coloniality. His work addressed the pessimistic outlook for decolonisation, but also offered the possibility that third-world anti-colonial movements could escape 'the nation' in their pursuit of independence, if they avoided the pitfalls he identified, and implemented his prescriptions for successful decolonisation.

While his work is rich in its prescriptions (detailing the pitfalls of decolonisation, the power of colonial individualism, and the significance of the peasantry) I focus here on his opposition to artificial "frontiers" which prevented regional unity, and the need for a more sustainable intellectual foundation to anti-colonialism, which he termed national consciousness. On this matter he stated: "[n]ational consciousness, which is not nationalism, is alone capable of giving us an international dimension” (2001: 199). For Fanon, this 'international dimension' was a crucial bulwark against the "[o]ld rivalries which were there before colonialism" as well as "old interracial hatred" that were harboured and nourished by the 'nationals' (2001: 129). He went on to argue that this national consciousness should contain a deliberate connection with the efforts of past generations (2001: 166) and pre-colonial histories that the colonisers sought to eradicate (2001: 169). For Fanon this entailed a revival and cultivation of solidarities and identities that preceded and transcended the nation, and embraced not national but pan-regional identities (2001: 170). To highlight the possibility of this international vision, Fanon used Arab pan-regional connectedness as a positive example:

Today, Arab doctors and Arab poets speak to each other across the frontiers, and strive to create a new Arab culture and a new Arab civilisation. It is in the name of Arabism that these men join together, and that they try to think together. Everywhere, however, in the Arab world, national feeling has preserved, even under colonial domination, a liveliness that we fail to find in Africa. (2001: 172) 
If national consciousness was an alternative to national self-determination, then similarly, national culture offered an alternative to racial culture, and would help to bring about true psychological, social, economic and political emancipation - all things that countered any aspiration for inclusion in a 'family of nations' whose gate-keeper was the west. It is important to separate the notions here: Fanon was deeply critical of the nation and even nationalists, and (despite the use of the word 'national') saw national consciousness as a mental emancipation from the oppression of the colonisers and the colonial nation-state.

However, one might ask whether Fanon was radical enough. Fanon's exemplification of Arabism and importance given to national culture appears to be in tension with his prescription for decolonisation of an international dimension. While Fanon's focus on pan-African and panArab solidarities does more closely reflect his call for that international dimension, his praise of 'national cultures' as a resistance to regional cultures (what he considers to be teetering towards racialised cultures, and therefore a product of colonialism) undoes some of the creative potential of his initial rejection of colonially-imposed frontiers.

Furthermore, Fanon still retained the language of nationalism, inherited from the colonisers. Christopher Miller has argued that this should not be dismissed as a simple matter of semantics, but that it has real implications for Fanon's theory of decolonisation, which in his view persists with a Eurocentric course (Miller, 1990: 48). Others have argued that Fanon does not really provide an alternative to the concept of the 'national' but rather his "critique of bourgeois nationalist ideology was itself delivered from an alternative nationalist standpoint" (Lazarus, 1993. Italics used in original text). This would explain why the term nationalist is used interchangeably to both critique the bourgeoisie, or native intellectuals, while also lauding the revolutionary spirit 
of anti-colonial natives who work for 'the nation'. The potency of the colonial-nationalist imaginary is evident from the ease with which its concepts and language are borrowed even within the realms of resistance. In recognition of the challenge posed, Thompson queries whether one can ever think beyond "methodological nationalism" and the "container" of the nation-state, given their hegemony (2013: 140); but as she and Shilliam (2006) both note, non-nationalist networks and historical entities, such as the Atlantic slave trade, empire or lingua-spatial connections such as the 'Anglosphere', do offer conceptual and discursive alternatives - alternatives which arguably were not sufficiently exploited by Fanon in lieu of the 'national'.

Secondly, Fanon's example of Arabism as a successful example of pan-regional solidarity, notably written during the 1960s heyday of Arab nationalism across the region, raises further contentions. Arab nationalism - Nasserist and Ba'thist - struggled with the very pitfalls Fanon laid out in such detail, and just as it had the capacity to unite across Arab and even other thirdworld frontiers, it also had the capacity to fragment existing solidarities at home. Even prior to the rise of militarist, socialist Arab nationalism of the 1950s and 60s, Arabism in its more intellectual and bourgeois form contained elements of supremacism and racism. Moreover, the writings of At-Tahtawi, Kawakibi and Antonius, for example, strongly eulogised the west, and applied the same hegemonic militarist and masculinist tropes to Arab identity and history that were used by European nationalists. Rather than discard this colonial discourse, much of it was in fact absorbed by their more anti-colonial, less bourgeois, successors.

This raises the question: is pan-regionalism sufficient to inoculate solidarities against the supremacism and racism that comes with nationalism and colonially-constructed frontiers? On its own, clearly not; which is why Fanon went to great lengths to articulate the importance of na- 
tional consciousness as a necessary condition for the revival and reformulation of pre-colonial, pan-regional solidarities. Just how far this can prevent eventual entrapment in the web of coloniality will be explored in the next section.

Despite its emancipatory intent, it is interesting that the majority of The Wretched of the Earth is dedicated to highlighting the pitfalls that accompany decolonisation - Fanon was well aware of the difficulties of escaping the bondage of the natives to their former colonial masters even after nominal freedom. In many ways the scene is set in his work for an inescapable tragedy: that despite the latent potential for national consciousness, any decolonial project remains doomed to be shaped by the shackles of colonisation.

\section{The Muslim Brotherhood and the Caliphate as a Decolonial Project}

The Muslim Brotherhood was set up by Hasan Al Banna in 1928 in Egypt in the small town of Ismailiyya. By 1922 Egypt had already gained nominal independence, but British forces were still stationed in the country, had control of the Suez Canal and still pulled the strings in the country's domestic politics. Thus there were two primary motivations behind the creation of the Muslim Brotherhood: the first was religious reform of society in the face of increased secularisation, especially since the dissolution of the Ottoman Empire. The second goal, and quite deeply connected to the first, was to rid the country of British occupation and western influences that had, as Banna saw it, stripped Egyptians of their freedom, dignity, and religious spirit.

In the early phase of the Muslim Brotherhood, Hasan Al Banna refused to pursue a notion of independence that was tethered to the nation-state model, a point reflected in his writings and recollections of the early to mid-1930s. In contrast to the Wafd nationalists, one of the oldest par- 
ties in opposition to the British, Banna set out an ideology of independence that consciously rejected those western frameworks he deemed incompatible with true autonomy and Islam. Instead of seeking decolonisation for the sake of national self-determination, Banna's attachment to Egypt was very much through the prism of his faith, as he expressed in his memoirs which recounts his early life up until 1932:

I felt my cherished Egyptian nation as torn between the two conflicting ideologies. On the one hand there was their revered faith, Islam, which they had inherited and preserved at all cost...And on the other hand there was a fierce attack of the western thought and culture to destroy the old values of life. (Banna, 1982 [first published in 1947]: 110-111).

One such alien culture that Banna saw as a chief threat was nationalism. He did not see (or want to see) nationalism, or the establishment of an independent nation-state, as the end product of decolonisation. For him, the end of that struggle was a restoration of Egypt's spiritual foundations, as he saw it. He laid out the priority of Egyptians to be: "[L]iberation of the homeland from all 'un-Islamic' or foreign control, whether political, economic or ideological'. (Banna, 1978a: 15).

As further evidence of Banna's rejection of western models of nationhood, he elucidated an opposition to loyalty based on ethnic or racial lines when stating the following: ...Just as Islam is a faith and worship, it is also nationhood. All racial or ancestral distinctions except this are false. God the sublime says: 'The believers are but a single Brotherhood' (Surah 49: 10). Similarly the Prophet peace be upon him said 'A Muslim is the brother of a Muslim.' Therefore all Muslims will be brethren...Even if a Muslim of subordinate position will give refuge to anybody, it shall be respected, and all shall be one against the enemies. Remember: Islam neither admits geographical differences; nor gives any importance to racial or blood distinctions...it takes all the Muslim countries as one nation, although there may be great distances between them..." (Banna, 1997: 28, my italics) 
Banna developed this in another treatise denouncing racism and arguing that this religious source of loyalty "transcended the bounds of mere geographical and ethnic patriotism to one of lofty principles." (Banna, 1978b, 159-160).

In these last two passages, Banna tread carefully towards a conceptual critique of the western nation-state and its inherent racist foundations. In an even clearer refutation of the racism embedded in the nationalist framework, Banna stated the following:

Some people say that this view [Muslim unity] is absolutely contrary to the present day prejudice of race and colour which is prevalent throughout the world. They say that today the world is being carried by the tide of racism. 'How will you stand against this flood? How will you go against all the people?' The answer to this question is that people are mistaken; and the results of these mistakes can be felt in the dissatisfaction of the nations and the related destruction. Then it is not the duty of the physician to agree with the patients. It is the duty to treat them and to show them the correct path. (Banna, 1997: 28-29)

In these passages, it becomes clear that Banna was rebuffing Wilson's prescription of the nation, explicitly identifying the nation-state model as racist, and forging an alternative imagining of decolonisation. This critique culminated with his declaration of a longterm aspiration for the Khilafah (Banna, 1997: 30). He challenged those who argued that it would be easier to work within the nation-state model by stating that "it is easier to repeat" Islam's earlier accomplishments of uniting people across geographical boundaries, "than to imitate" western nationalism. Again, with Banna's commitment to learning from a pre-colonial past, belonging not just to Egypt but other colonised communities, we see a parallel with Fanon's call to revive the transnational histories erased by the colonisers. 
It is worth noting here that the historical reality of a clearly defined Muslim world, or a past territorial unity of Khilafah, is a contested one. As several scholars have argued, the notion of a Muslim world was consolidated via the racialisation of Muslims during European colonisation, and was far more disparate and fluid prior to that (Aydin, 2017b; Yenigun, 2017; Sunar 2017). Even so, as Aydin acknowledges, this does not negate the concept of a deterritorialised Ummah (2017a: 18), a concept which is "as old as Islam itself". Indeed, Banna was aware of Muslim thinkers and anti-colonial movements in other parts of the colonised world - this sense of transnational connectivity, though ironically facilitated by colonialism, produced a pre-colonial imaginary which (real or not) played an important part in Banna's belief in an emerging epoch of faithful revival. The very idea that Mujaddids (Muslim revivalists) were emerging in distant countries was in fact pivotal to his decolonial methodology and gave impetus and purpose to the Muslim Brotherhood's resistance to the British in Egypt, and Israel in Palestine. Banna idealised Islam and its history; but it was not merely nostalgia - through his idealisation he sought to build a future decolonial project for fellow Egyptians, which for him, connected to similar islamicate projects in other parts of the world. As his writings suggest, and even moreso with Sayyid Qutb and his intellectual borrowings from Sayyid Abul ala Mawdudi in India, the ability to imagine an alternative political community to the one proffered by the west provided them with motivation in their actions and writings, however hopeless an endeavour it might have seemed to onlookers.

According to Sayyid, the Caliphate offered a metaphor for Muslim autonomy - to even "meditate upon the dangerous impossibility of the Caliphate" was itself subversive. As he argues, it not only threatened to overturn the existing colonial system, but its very impossibility also forced the adherent to confront the dilemma between "aspirations to reorder the postcolonial 
world and the investments in the continuation of the violent hierarchies of coloniality." (2014: 15). The very concept of Khilafah thus posed not only a challenge to the real world order, but also shone a light on one's internalised coloniality. It inadvertently became a manifestation of the religious injunction for muhaasabah, self-accountability and self-critique. In other words, it was an embodiment of the national consciousness and fear of complacency that Fanon spoke of. From this perspective, it matters not whether the Khilafah was a historical reality or a figment of anti-colonial Muslim imagination - indeed the audacity to imagine, and thus produce a language alternative to the 'national', was in fact an expression of resistance.

Additionally, and in contrast to contemporary anti-colonial groups in Egypt, the Muslim Brotherhood disseminated a tarbiyah (education) programme across Egypt that would rigorously monitor members' development. The Usrah (cells), katibah ('battalions' in which several 'usrahs' would gather on a monthly basis), rihlah (physical training trips), and mu'tamar (annual conferences) were used to create a sense of identity and solidarity between members dispersed across the country, as well as instill cohesion and structure to the Muslim Brotherhood's ideology and methodology. This programme trained members in religious knowledge (such as hadith, Qur'an, Islamic laws, interpretation of Islamic society, Islamic history, and the life of the Prophet); physical exercise; political engagement; cultural awareness; and in some cases military training, to ensure they went beyond mere dissatisfaction of foreign occupation to producing actual resistance (Banna, 1982: 142-143). These methods were first and foremost designed to strengthen piety among the members, but in doing so it was fully intended that the members would act as a bulwark against the colonial destruction of Egypt's values and way of life. The Brotherhood's tarbiyah system reflects Fanon's call for deeper political consciousness that went beyond just a 
physical reaction to colonialism. Moreover, the solidarities that were built in these cross-country tarbiyah programmes helped to foster an alternative sense of community beyond a nationalist one.

\section{Decline of the Brotherhood's Decolonial Project: Embracing Nationalism and the Nation-}

\section{State}

As the Muslim Brotherhood spread across the country and increased its membership and influence, Banna had to go to greater lengths to explain and justify the differences between his religious anti-colonialism on the one hand and national self-determination on the other. It was a tension he was personally untroubled by when first setting up the organisation, but which continued to elicit much debate and dilemma as the Brotherhood became a greater rival to the nationalist Wafd party, and a more credible opponent to the British. The power that nationalist discourse held in Egypt is clear from the amount of space Banna dedicated in his tracts to debating the relationship between nationalism and religion - these were all meant for a public audience. In contrast, Banna gave no appeasement to nationalist sentiment in his memoirs, arguably a greater reflection of his personal ideology, and a sign that he was not personally affected by any dilemma between faith and nation; but also intended as instruction for close followers of the movement (Lia, 2015).

Yet Banna did not have the luxury of silence on the topic when engaging with the Egyptian public. In his tract in 1938 that was meant to announce the political ambitions of the Muslim Brotherhood on the national stage, he instilled some ambiguity on the subject. Under the heading, "Stances of the Muslim Brotherhood in respect of National, Arabian and Islamic unities", he 
argued that the Brotherhood did not necessarily outlaw nationalist sentiment, as long as it was simply used for the purposes of achieving greater unity, first among the Arabs and then amongst Muslims in other parts of the world (1997: 28). With the spotlight of critics very much centred on the movement by 1938, Banna appeared hesitant to publicly criticise the concept of nationalism directly, partly due to his belief in avoiding debates that caused disunity (amongst the wider public but also within the movement), and partly because Banna wanted to reach out to wavering secularists. He appeared to concede to Arab nationalist claims of superiority when arguing " $\mathrm{t}] \mathrm{he}$ Arabs are the pillars of Islam and its protectors" (1997: 28).

Though Banna only accepted nationalist sentiment as a stepping stone towards loftier goals that were inspired by faithful solidarity, and as stated paid no homage to Arab nationalist sentiments in his memoirs or earlier tracts, this introduction of ambiguity was significant. It allowed room for a more substantial form of nationalism to creep into the Brotherhood's ideology after Banna's assassination in 1949. Indeed Banna's opposition to the nationalist Wafd and the monarchy had already been criticised by a faction of his own members before then (Lia, 2015). This provides us with the first indication as to how and why the Brotherhood departed from its early decolonial project.

The second cause for this departure was more sudden and traumatic. In 1952 the Free Officer movement, led by the charismatic Gamal Abdel Nasser, took control of Egypt in a military coup. Almost overnight, the corrupt monarchy, the British-controlled government, and the ineffectual accommodationist Wafd nationalists, were all eliminated from Egyptian politics. While old Arab nationalist intellectuals had distanced themselves from the Egyptian masses with their internalised orientalism, these 'new' Arab nationalists restored Arab dignity by standing up to the 
west. The nationalist military regime of Nasser exploited the lack of legitimacy of the Wafdist nationalists, challenged British occupation forcefully, opposed Israel, established effective social contracts with the Egyptian public (Wickham, 2002 :23), and in doing so moved on to the Muslim Brotherhood's turf.

The Brotherhood feared Nasser had usurped their role as the 'official opposition' to the colonisers, hard won over the years, and not without good reason. Nasser and his officers initially challenged the limited scope of the western nation-state model, advocating regional loyalties, both pan-Arab and pan-African, and briefly entered into a union with Syria in 1958. Nasser united Arab nationalism with socialism so that the ideology and his regime would claim an attachment to the lower classes. Moreover, despite the Brotherhood's efforts to portray Nasser as 'antiIslam', he was quite adept at deploying religious symbolism and rhetoric, and expressing pride in his Muslim identity (Nasser, printed in Haim, 1962: 229-233). In these ways the Arab nationalist regime in Egypt, like its Ba'thist allies in Syria, seemed to be pursuing a 'Third Worldist', not a western-Wilsonian, route to decolonisation. Moreover, it was a model that seemed to earn the adulation of people on the street, as true anti-colonialists might, and the grudging respect of their enemies; in the 1950s both the United States and the Soviet Union were vying for political and economic treaties and arms deals with Nasser's Egypt. The ensuing competition between Nasser and the Muslim Brotherhood instilled in them both an existential drive to monopolise the anticolonial, anti-hegemonic terrain (Gerges, 2018: 93-95). Devastatingly for both sides, this pursuit of power produced the usual dynamics of oppression: as Fanon stated, "[ $\mathrm{t}]$ he native is an oppressed person whose permanent dream is to become the persecutor" (2001: 41). Once the British were ousted in the Suez debacle of 1956, the Muslim Brotherhood and other domestic 
dissenters became the new target of Nasser's regime, and the othering that is inherent to nationalism found its way into the regime's demonisation and persecution of the Muslim Brotherhood.

With this increased repression, and without Banna's vision and leadership, the Muslim Brotherhood were faced with not just an organisational crisis, but an ideological one too. With decolonisation sweeping across the region, it was nationalism in anti-colonial garb that gained new adherents - inextricably melded as it had been with self-determination - not the Brotherhood's aspiration for the Khilafah. The latter was criticised as outdated, an endorsement of the corrupt and non-Arab Ottoman empire, and even imperialist. The Muslim Brotherhood was caught in what Mignolo terms a "double bind" (2002: 70-72): judged for offering nothing distinctive from what already had preceded (and failed), or judged to be so different that their viability always remained in doubt.

\section{Evolution of the Muslim Brotherhood and Normalising Nationalism}

The Muslim Brotherhood's reaction was to split between two intellectual approaches.

One faction was spearheaded by the former secular-liberal, literary critic turned Brotherhood member, Sayyid Qutb. He advocated rejectionism and ultimately violence against the 'atheist' Arab nationalist usurpers. Thinly veiled attacks on Nasser via denunciations of Marxism and nationalism are numerous in some of his most important works: Fi Zilal ul Qur'an (In the Shade of the Qur'an), a multi-volume exegesis of the Qur'an, and more explicitly in Ma'alim fi-t Tariq (Milestones) for which he was eventually executed by Nasser's regime in 1966. Writing under the strains of imprisonment and torture, his works ignited a train of subversive religio-decolonial 
discourse that was received by fellow Muslim Brotherhood members as either revolutionary or dangerous.

The second faction sought to reprise Banna's early, less confrontational methods of $D a$ 'wah (invitation to Islam) combined with successful elements of the Arab nationalist formula in order to avoid repression by the regime and to regain the ascendance they had enjoyed amongst Egyptians in the late 1940s. This bifurcation became more pronounced with the publication Du'at la Qudah (Preachers not Judges) in 1969 by the Supreme Guide at the time, Hasan al-Hudaybi. That faction of the Muslim Brotherhood, through little choice of their own, became so preoccupied with escaping Nasser's dungeons and a shut-down of even their most basic welfare work, that they eschewed their radical, revolutionary, decolonial spirit which reached its practical and ideological peak with Banna, and its conceptual extremes under Qutb. The regime's violent reaction frightened many of the Muslim Brotherhood's followers into a more conformist route, while others left the group to form more extreme off-shoots such as Islamic Jihad.

One of the ways in which this conformity can be detected is via the Brotherhood's changing attitudes towards nationalism. The initial success of the Muslim Brotherhood in charting a decolonial path had been clear from their confident dissociation from nationalism (both ideologically and in terms of Egypt's party politics), and their indifference to being marginalised by the British. But increasingly, the ambiguity on the role of nationalism that Banna had himself belatedly instilled into his discourse for strategic, instrumental reasons, became a justification for increased nationalistic sentiment amongst the organisation's thinkers and professional classes. One of these, Muhammad Al Ghazali, in his depiction of Islamic history partly attributed the decline of Islam to the increased role of non-Arabs in the Islamic caliphate under the Abbasids, pinning 
particular responsibility on the Persians and the Turks (1950-1: 172-9). Indeed some of this was taken from Banna's own official Rasa'il, such as Bayna Al-Ams wa'l Yawm (Between Yesterday and Today) in which he attributed the 'diluted Islam' of the Persians and the Turks to their lack of Arabic and thus lack of deeper access to the meaning of the scriptures (cited in Mitchell, 1969: 211). If this was stated of the Turks and the Persians (many of whom lived and travelled through Arab societies, and would have learnt Arabic as the lingua franca of the Ottoman Empire) what was the Brotherhood's position on Muslims in the Indian subcontinent, South-East Asia or Africa, who carried even greater pluralism of cultures, languages and non-monotheistic religious histories? These global communities had their own rich narratives of local Muslim empires, but notably they were not referenced in these commentaries even for the purposes of critique - the erasure in itself can be seen as a reproduction of European racial hierarchies and civilisational discourse (Gani, 2017).

This demonstrates the porosity of even decolonial positions, and the potency of nationalist norms that then act as a vehicle for supremacism. As Wickham points out (2013, xi), one cannot always view such evolutions as merely strategic, but in many cases they reflect more substantive changes in thought and ideology. As the Muslim Brotherhood spread beyond Egypt and became features of neighbouring Arab societies, there emerged a convenient and immutable overlap between a popular Arab nationalist solidarity and the Muslim Brotherhood's pan-regional network.

Banna's initial painstaking separation between an unacceptable nationalistic patriotism and solidarity with one's fellow countrymen and women increasingly gave way to quiet accommodation for Arab nationalist romanticism and even Arab supremacism as reflected by its mem- 
bership's interpretation of Islamic history. Despite the fact a simultaneous decolonial, Islamic revivalist movement was under way in the Indian subcontinent, whose own leader Sayyid Abul Ala Mawdudi was said to have had a profound intellectual impact on Banna and Qutb (Mandaville, 2009; Tripp, 2006: 155), Muslim Brotherhood education programmes and scholarly output centred on the importance of historical events and thinkers of the Middle East. The organisation's teaching of Islamic history was, and in most cases still is, confined to the history of the Arab region and the Ottoman Empire - some justification for this approach is gleaned from the Brotherhood's early conferences, which were so closely aligned to the discourse of Arab nationalists that it was hard to see a difference between their political goals. To highlight this point, in a respected and oft-used publication of the Brotherhood's educational methodology, any discussion of ummah predominantly alludes to the Arab world and at best the Middle East, where often the author's knowledge and interest ends (Abdal Haleem, 2003: 40 and 58). In the author's reading of history, the term "the Arab and Muslim nation" is used frequently, while Arabs, Muslims and Islam are often used interchangeably (2003: 479-80). When the author addresses the "state of politics in the Muslim world", he focuses on the former Ottoman empire, the Crusades and the specific history of the Muslim Brotherhood (2003: 436). When he outlines the need to understand the 'plight' of the Muslim world, a lengthy discussion ensues on Palestine, except for the briefest mentions of Indonesia and Pakistan (2003: 458-9).

While this focus on countries of geographical proximity might have some justification in Egypt, the strong nationalist undertones become even more noticeable when this ethnocentric view of the ummah is reproduced amongst Muslim Brotherhood diaspora and affiliates in western countries (Brooke, 2012: 31-33; Vidino, 2012: 57-64). Thus, as the movement evolved, 
Banna's call for non-territorial solidarity between believers across the globe was still nominally acknowledged, but did little to mask the provincialism of the Muslim Brotherhood's actual conceptualisation and practice of ummah.

Beyond this infiltration of a soft Arab supremacism in Muslim Brotherhood teaching and practice, their political agenda became moulded around national priorities and as Leiken and Brooke (2007) argue, conformist with the nation-state. Thus Muslim Brotherhood policies and strategies are contingent on which Arab state they happen to be operating in, producing a significant amount of divergence that goes beyond situational adaptation and call into question ideological consistency.

\section{Conclusion}

Woodrow Wilson's tethering of decolonisation to the nation-state model produced a tragedy for colonised people seeking autonomy from an imperialist framework. In resistance to this colonial trap, Fanon set out a blueprint for anti-colonial movements to not only gain territorial independence but to dismantle the coloniality programmed into the very foundations of indigenous politics, society and culture of newly decolonised 'nations'. Two strategies laid out by Fanon to facilitate this emancipation were transnational solidarities and national consciousness.

This article demonstrates ways in which the Muslim Brotherhood in Egypt under the leadership of its founder Hasan Al Banna succeeded initially in pursuing a decolonial, non-nationalist project that mirrored, perhaps even helped to inform, Fanon's own vision. The article explored two prominent decolonial facets of Banna's ideology and methods that reflected a Fanonian approach: 1) the snubbing of a supremacist nationalist identity and rejection of a west- 
ern nation-state model; and 2) the cultivation and dissemination of a comprehensive educational programme to instil deep, long term political consciousness among its followers. This educational programme helped foster an alternative to nationalist belonging via the notion of Ummah and Khilafah, and also exemplified the possibility of alternative non-nationalist solidarities. However, despite such firm decolonial credentials, the pressures of nationalist competition and disparagement on the one hand, and state repression on the other, caused the Brotherhood to drift over the decades from its decolonial foundations and to fall in line with a nationalist, modernist, and at its roots, colonial, epistemology.

The culmination of this analysis confirms the tragedy in the search for postcolonial independence, and demonstrates how hard it is to undo the colonial tethering of nationalism to decolonisation. Fanon put forward a programme of decolonisation that is supposed to re-imagine independence beyond the confines of the nation-state project. His prescriptions of pan-regional solidarities that restore the international dimension to decolonising strategies, and national consciousness that binds anti-colonial groups to the principle of justice rather than parochial, classbased, racial loyalties, are evident in the Muslim Brotherhood's early ideological vision. And yet, these strategies were not enough to prevent implicit ideological and practical concessions to nationalism, and an internalisation of the nation-state framework that reproduced the very coloniality the organisation was meant to escape.

\section{References}

Abdal Haleem, Ali. 2003. Methodology of Education Adopted by the Muslim Brotherhood. Cairo: Islamic Inc. Publishing. 
Aydin, Cemil. 2017a. The Idea of the Muslim World: A Global Intellectual History. Cambridge, MA: Harvard University Press.

Aydin, Cemil. 2017b. "Beyond Civilization: Pan-Islamism, Pan-Asianism, and the Revolt against the West." In Debates on Civilization in the Muslim World: Critical Perspectives on Islam and Modernity, ed. L. Sunar. New Delhi: Oxford University Press.

Al-Banna, Hasan. 1978a. "The Message of the Teachings." In Majmu'at Rasail. Kuwait: International Islamic Federation of Student Organizations.

Al-Banna, Hasan. 1978b. “To What Do We Invite Humanity?” In Majmu'at Rasail. Kuwait: International Islamic Federation of Student Organizations.

Al-Banna, Hasan. 1982. Memoirs of Hasan Al Banna Shaheed. Karachi: International Islamic Publishers.

Al-Banna, Hasan. 1997. The Message of the Fifth Conference. Al-Ikhwan-Al Muslimoon Press. Bernasconi, Robert. 2011. "Kant's Third Thoughts on Race.” In Reading Kant's Geography, eds. S. Elden and E. Mendieta, Albany: SUNY Press.

Bhabha, Homi. 1991. “A Question of Survival: Nations and Psychic States.” In Psychoanalysis and Cultural Theory: Thresholds, ed. J. Donald. New York: St. Martin's Press.

Brooke, Steven. 2012. "The Muslim Brotherhood in Europe and the Middle East: The Evolution of a Relationship." In The Muslim Brotherhood in Europe, eds. R. Meijer and E. Bakker. London: Hurst \& Company.

Dunbar-Ortiz, Roxanne. 2018. A Disarming History of the Second Amendment. San Francisco: City Lights Publishers.

Fanon, Frantz. 2001. The Wretched of the Earth. London: Penguin Classics. 
Forsythe, Dennis. 1973. "Frantz Fanon: The Marx of the Third World." Phylon 34(2): 160-170.

Gani, J. K. 2017. "The Erasure of Race: Cosmpolitanism and the Illusion of Kantian Hospitality". Millennium: Journal of International Studies 45(3): 425-446.

Garfinkle, Adam M. 1991. “On the Origin, Meaning, Use and Abuse of a Phrase.” Middle East Studies 27(4): 539-550.

Gerges, Fawaz A. 2018. Making the Arab World: Nasser, Qutb, and the Clash That Shaped the Middle East. Princeton: Princeton University Press.

Goldberg, David Theo. 2002. The Racial State. Malden, MA: Blackwell.

Haim, Sylvia. 1962. Arab Nationalism: An Anthology. Berkeley: University of California Press.

Hudaybi, Hasan. 1977. Du 'àt lā Quḍ̂̄t. Cairo: Dār al-Ṭibā'ah wa al-Nashr al-Islāmīyah.

Khalid, Khalid M. and Muhammad Ghazali. 1950-1. From Here We Start and from Here We Know. Translation, Ismail Raji al-Faruqi. Kuala Lumpur: Islamic Book Trust.

Kotob, S. A. 1995. "The Accommodationists Speak: Goals and Strategies of the Muslim Brotherhood of Egypt.” International Journal of Middle East Studies 27(3): 321-339.

Lazarus, Neil. 1993. "Disavowing Decolonization: Fanon, Nationalism, and the Problematic of Representation in Current Theories of Colonial Discourse." Research in African Literatures 24(4): 69-98.

Leiken, Robert S. and Stephen Brooke. 2007. "The Moderate Muslim Brotherhood.” Foreign Affairs 86(2): 107-121.

Lia, Brynjar. 2015. “Autobiography or Fiction? Hasan al-Bannā’s Memoirs Revisited.” Journal of Arabic and Islamic Studies, 15 (2015): 199-226, Department of Culture Studies and Oriental Languages, University of Oslo, Norway 
Mandaville, Peter. 2007. Global Political Islam. London: Routledge

Mignolo, Walter. 2002. "The Geopolitics of Knowledge and the Colonial Difference." South Atlantic Quarterly 101(1): 57-96.

McCarthy, Thomas. 2009. Race, Empire, and the Idea of Human Development. Cambridge: Cambridge University Press.

Meijer, Roel and Edwin Bakker (eds.). 2012. The Muslim Brotherhood in Europe. London: Hurst \& Company.

Miller, Christopher. 1990. Theories of Africans: Francophone Literature and Anthropology in Africa. Chicago and London: University of Chicago Press.

Mitchell, Richard. 1969. The Society of the Muslim Brothers. London: Oxford University Press. Mitchell, Timothy. 1988. Colonising Egypt. Berkeley: University of California Press.

Nursey-Bray, Paul. 1972. "Marxism and Existentialism in the Thought of Frantz Fanon." Political Studies 20(2): 152-168.

Pankhurst, Reza. 2013. The Inevitable Caliphate? A History of the Struggle for a Global Islamic Union, 1924 to the Present. London: Hurst.

Persaud, Randolph B. 2002. "Situating Race in International Relations: The Dialectics of Civilizational Security in American Immigration." In Power, Postcolonialism and International Relations: Reading Race, Gender and Class, eds. G. Chowdhry and S. Nair. London: Routledge.

Povey, Tara. 2015. Social Movements in Egypt and Iran. London: Palgrave Macmillan. Quijano, Anibal. 2000. “Coloniality of Power and Eurocentrism in Latin America.” International Sociology 15(2): 215-232. 
Rabaka, Reiland. 2011. “Revolutionary Fanonism: On Frantz Fanon's Modification of Marxism and Decolonization of Democratic Socialism." Socialism and Democracy 25(1): 126-145.

Roy, Olivier. 2004. Globalised Islam: The Search for a New Ummah. London: Hurst.

Sabaratnam, Meera. 2011. "IR in Dialogue...but Can We Change the Subjects? A Typology of Decolonising Strategies for the Study of World Politics." Millennium: Journal of International Studies 39(3): 781-803.

Sajed, Alina. 2013. "Fanon, Camus and the Global Colour Line: Colonial Difference and the Rise of Decolonial Horizons." Cambridge Review of International Affairs 26(1): 5-26.

Salem, Sara. 2018. "Reading Egypt's Postcolonial State Through Frantz Fanon: Hegemony, Dependency and Development." Interventions: International Journal of Postcolonial Studies 20(3): 428-445.

Sayyid, S. 2014. Recalling the Caliphate. London: Hurst \& Co Publishers Ltd

Seth, Sanjay. 2011. "Postcolonial Theory and the Critique of International Relations." Millennium: Journal of International Studies 40(1): 167-183.

Sharif, Regina. 1976. “Christians for Zion.” Journal of Palestine Studies 5(3/4): 123-141

Shilliam, Robbie. 2006. "What about Marcus Garvey? Race and the transformation of sovereignty debate." Review of International Studies 32(3): 379-400

Sunar, Lufti. (ed.). 2017. Debates on Civilization in the Muslim World: Critical Perspectives on Islam and Modernity. New Delhi: Oxford University Press.

Thompson, D. 2013. “Through, against and beyond the Racial State: The Transnational Stratum of Race.” Cambridge Review of International Affairs 26(1): 133-151. 
Tibi, Bassam. 1997. Arab Nationalism: Between Islam and the Nation-State. London: Palgrave Macmillan.

Tripp, Charles. 2006. Islam and the Moral Economy: The Challenge of Capitalism. Cambridge: Cambridge University Press.

Vidino, Lorenzo. 2006. “Aims and Methods of Europe's Muslim Brotherhood.” Current Trends in Islamist Ideology 4: 22-44.

Vidino, Lorenzo. 2012. "The European Organisation of the Muslim Brotherhood: Myth or Reality?" In The Muslim Brotherhood in Europe, eds. R. Meijer and E. Bakker. London: Hurst \& Company.

Vitalis, Robert. "Birth of a Discipline." In Imperialism and Internationalism in the Discipline of International Relations, eds. D. Long and B. C. Schmidt. New York: SUNY Press.

Vitalis, Robert. 2015. White World Order, Black Power Politics: The Birth of American International Relations. Ithica, NY: Cornell University Press

Voll, John. 1969. "Foreword.” In R. Mitchell, The Society of the Muslim Brothers. London: Oxford University Press.

Wickham, Carrie. 2002. Mobilizing Islam: Religion, Activism and Political Change in Egypt. New York: Columbia University Press.

Wickham, Carrie. 2013. The Muslim Brotherhood: Evolution of an Islamist Movement. Princeton: Princeton University Press.

Yenigun, Halil. 2017. "The Rise and Demise of Civilizational Thinking in Contemporary Muslim Political Thought." In Debates on Civilization in the Muslim World: Critical Perspectives on Islam and Modernity, ed. L. Sunar. New Delhi: Oxford University Press. 
Zollner, Barbara. 2011. The Muslim Brotherhood: Hasan al-Hudaybi and Ideology. Abington and New York: Routledge. 